\title{
A review of the impact of obesity on common gastrointestinal malignancies
}

\author{
Somashekar G. Krishna ${ }^{1 *}$, Hisham Hussan ${ }^{2}$, Zobeida Cruz-Monserrate ${ }^{3}$, Lanla F. Conteh ${ }^{4}$ Khalid Mumtaz $^{4}$ and Darwin L. Conwell $^{5}$ \\ ${ }^{1}$ Sections of Pancreatic Disorders and Advanced Endoscopy, Division of Gastroenterology, Hepatology and Nutrition, Comprehensive Cancer Center, The Ohio \\ State University Wexner Medical Center, USA \\ ${ }^{2}$ Sections of Intestinal Neoplasia and Hereditary Polyposis, and Obesity and Bariatric Endoscopy, Division of Gastroenterology, Hepatology and Nutrition, \\ Comprehensive Cancer Center, The Ohio State University, USA \\ ${ }^{3}$ Section of Molecular and Cellular Biology, Division of Gastroenterology, Hepatology and Nutrition, Comprehensive Cancer Center, The Ohio State University \\ Wexner Medical Center, USA \\ ${ }^{4}$ Section of Hepatology \& Comprehensive Transplant Center, Division of Gastroenterology, Hepatology and Nutrition, Comprehensive Cancer Center, The Ohio \\ State University Wexner Medical Center, USA \\ ${ }^{5}$ Section of Pancreatic Disorders, Division of Gastroenterology, Hepatology and Nutrition, Comprehensive Cancer Center, The Ohio State University Wexner \\ Medical Center, USA
}

\begin{abstract}
Obesity is a global pandemic and is a well-recognized risk factor for various gastrointestinal diseases. The prevalence of obesity is increasing across all age groups. There is an emergent need for focused guidelines aimed at reducing the incidence, prevalence, and associated risks of obesity. The impact of obesity on gastrointestinal cancers being multifactorial adversely influences the associated risk, disease course, prognosis, and overall survival. We have summarized the current literature highlighting the association between obesity and common gastrointestinal cancers, with specific focus on esophageal adenocarcinoma, colon cancer, hepatocellular cancer, cholangiocarcinoma, and pancreatic malignancies.
\end{abstract}

\section{Introduction}

Nearly $30 \%$ of the world's population is overweight or obese, and none of the countries in the world have been successful in reducing the obesity rates over the last 33 years [1]. In the United States (U.S), obesity has doubled in the last two decades and amounts to 78.6 million (34.9\%) of adults [2]. The prevalence of morbid obesity (Body Metabolic Index $[\mathrm{BMI}]>40$ ) is rapidly increasing with an approximate $70 \%$ growth in the last decade [3]. Likewise, childhood obesity which predicts the impending future, has more than doubled in children and quadrupled in adolescents in the last three decades [2].

The evidence linking the obesity pandemic to various gastrointestinal cancers is mounting. The data are a mixture of observational, retrospective and a few prospective studies. A forecast of the imminent health and economic burden of obesity in 2030 estimated that continuation of prevailing accumulative trends in obesity will lead to about 500,000 additional cases of cancer in the U.S. by 2030 [4]. Obesity not only increases cancer risk, but also diminishes survival of cancer patients [5]. Although the relationship is not linear for a few malignancies, continued research is warranted to establish clear risks and associations. This review summarizes the current literature associating obesity to gastrointestinal cancers, specifically, cholangiocarcinoma, esophageal, gastric, hepatocellular, pancreatic, and colorectal malignancies.

\section{Esophageal cancer}

Several studies have reported that overweight and obese patients are more often diagnosed with esophageal adenocarcinoma. A
Mendelian randomized study analyzing 999 patients with esophageal adenocarcinoma, 2,061 patients with Barrett's esophagus, and 2,169 population controls demonstrated that the risk of adenocarcinoma of the esophagus and Barrett's esophagus increased by $16 \%$ and $12 \%$ per $1 \mathrm{~kg} / \mathrm{m}^{2}$ increase in BMI, respectively [6]. A meta-analysis has demonstrated that a higher BMI range (BMI of 30 to $34.9 \mathrm{~kg} / \mathrm{m}^{2}$ vs. < $25 \mathrm{~kg} / \mathrm{m}^{2}$ ) contributed to a 2.4-fold increase in the risk of esophageal adenocarcinoma [7]. The mechanisms of above associations are multifold - obesity increases intraabdominal pressure and risk of hiatal hernia and esophageal reflux disease, there are increased circulating levels of cytokines in patients with central obesity, associated metabolic syndrome is associated with Barrett's esophagus and adenocarcinoma, and a complex milieu of metabolic disorders in obesity appears to propel esophageal reflux disease to Barrett's esophagus and subsequent adenocarcinoma [8-12]. In addition to being a risk factor, there is accumulating evidence that obesity at the time of diagnosis of esophageal adenocarcinoma is an adverse prognostic characteristic influencing treatment outcomes [13].

\section{Colorectal cancer}

Colorectal cancer (CRC) is the third leading cause of cancer

Correspondence to: Dr. Somashekar G. Krishna, MD, MPH, Division of Gastroenterology, Hepatology and Nutrition, The Ohio State University Wexner Medical Center, 395 W. 12th Avenue, Ohio, USA, Tel: 614-293-6255, E-mail: sgkrishna@gmail.com

Received: December 23, 2016; Accepted: January 15, 2017; Published: January 18,2017 
incidence and mortality in the U.S [14]. Obesity is one of the strongest risk factors for colorectal neoplasia development accompanied by incremental risk with every 5-unit increase in BMI [15-19]. Experimental and epidemiological studies identified obesity as an independent risk factor for CRC irrespective of the impact of diet and exercise [20,21]. Furthermore, obesity's impact on CRC development was higher in men compared to women and more commonly seen in the colon compared to rectum [21,22]. This could be due to the differential impact of obesity in relation to colorectal embryonic origins or sex hormone levels. This well-established causality between obesity and CRC is of particular interest with the rising rates of obesity that can explain the incremental CRC incidence in patients younger than 50 of age in the U.S $[23,24]$.

The underlying mechanisms linking obesity to CRC are likely multifaceted. One well defined pathway is increased insulin resistance that has been associated with colorectal adenomas, CRC progression as well as larger tumor size [25-29]. This link was hypothesized to be through increased insulin-like growth factor 1 (IGF-I) levels and bioavailability seen with high insulin resistance [28,30]. Another major mechanism responsible for CRC is low grade inflammation seen in obesity with increased IL-1b, IL-6, TNF-a and NF-kB [31-33]. Finally, obesity is associated with leptin and decreased adiponectin [34]. Leptin can signal through the carcinogenic (JAK/STAT) pathway while adiponectin reduces pro-inflammatory cytokines via inhibition of (NF-kB) [35]. Indeed, a 3-fold increase in colon cancer risk was seen with increasing concentrations of leptin [36]. In addition to increase CRC incidence, obesity was associated with worse CRC outcomes. For instance, there was an increase in CRC-surgery perioperative morality, surgical complications and health-care utilization in association with morbid obesity [37]. Additionally, obesity was found to be associated with a greater risk of CRC recurrence following CRC diagnosis and treatment $[38,39]$. Finally, obesity was associated with inferior long term overall survival $[40,41]$.

\section{Pancreatic cancer}

Obesity is a significant risk factor for pancreatic adenocarcinoma (PDAC) [42-46]. This is concerning, as obesity rates are increasing worldwide, mostly due to increased consumption of a Western-style diet, high in fat and calories [47]. Epidemiological data indicates that preexisting obesity adversely influences PDAC-related mortality in a dose-dependent manner [5]. A meta-analysis and a pooled analysis of PDAC patients demonstrated a $10 \%$ and $14 \%$ increase in risk for each $5 \mathrm{~kg} / \mathrm{m}^{2}$ (above baseline of $30 \mathrm{~kg} / \mathrm{m}^{2}$ ) incremental increase in BMI, respectively $[48,49]$. A more recent study observed positive associations among measures of central obesity, waist circumference, and waist-tohip ratio with pancreatic cancer mortality [50].

Although many epidemiological studies have revealed association of obesity with PDAC affecting surgical outcomes, many issues about the underlying mechanisms remain unanswered. Utilizing genetically engineered mouse models, it has been demonstrated that diet-induced obesity acts as an inflammatory stimulus to trigger increased KRas activity [51]. Cyclooxygenase-2 (Cox-2) was also found to be critical in the inflammatory loop that leads to inflammation, increased fibrotic stroma, activation of KRas downstream signaling pathways, increases development of pancreatic intraepithelial neoplasia (PanIN) lesions, and decrease mice survival [51]. In addition, recent studies have demonstrated that increasing visceral obesity and associated sarcopenia adversely influence postoperative morbidity and long-term survival in PDAC [44,52-54]. Future research looking at factors derived from adipose tissue that could be promoting the development of PDAC are critical in an effort to develop preventative strategies.

\section{Hepatocellular cancer}

The incidence of hepatocellular carcinoma (HCC) is rapidly increasing and it is now the second most common cause of cancer related deaths worldwide. In 2016, it is estimated that more than 35,000 people in the U.S alone will be diagnosed with HCC. This number has been steadily increasing by about $3-4 \%$ annually over the last 10 years; overall, the incidence has tripled since the 1980 s $[55,56]$. Viral hepatitis was once the leading cause of HCC worldwide. However, non-alcoholic fatty liver disease (NAFLD) has now been recognized as a leading agent in the HCC epidemic. NAFLD affects more than 80 million Americans and ranges from simple hepatic steatosis to nonalcoholic steatohepatitis (NASH) which involves inflammation and injury at the cellular level and can progress to fibrosis and eventually cirrhosis. The rising prevalence of NAFLD directly reflects that of the metabolic syndrome and obesity pandemics [57]. Available data suggests that there is a 1.5 to 4 fold increased risk of HCC with obesity [58]. The mechanisms by which carcinogenesis is promoted remain unclear, however, proinflammatory cytokines, adinopectin, and insulin resistance have all identified as potential role players [57,59].

Diabetes mellitus alone has been identified as a negative prognostic indicator in patients with HCC. These patients have been shown to have a higher incidence of distant metastatic disease and a higher incidence of histological macrovascular invasion [60]. Although more prevalent in patients with cirrhosis, it is important to recognize that HCC can develop in patients with NAFLD in the absence of cirrhosis. Furthermore, there is increasing evidence that not only does NAFLD increase the risk of HCC, it may also increase the risk for tumor recurrence after treatment with locoregional therapy when compared to other etiologies of cirrhosis and HCC [61].

\section{Cholangiocarcinoma}

Data on association and pathogenesis of obesity with cholangiocarcinoma (CC) is emerging and, few epidemiologic studies have tried to assess this link [62-64]. Analysis of the Surveillance, Epidemiology, and End Results (SEER) - Medicare database reported a significant association between obesity and intrahepatic CC, but not between obesity and extrahepatic CC [63]. However, the significant limitation of this study was inclusion of patients $\geq 65$ years which might not be generalized to younger population. Also large database studies have chances of diagnostic bias due to the fact that obese people with various diseases are more likely to undergo testing and thus higher likelihood of a specific diagnosis. A Danish population-based study did not find significant association between obesity and CC [64]. This study has strengths of using complete national registry and histological confirmation of CC diagnosis. A study of the primary care database from the United Kingdom reported that patients with BMI $\geq 30 \mathrm{~kg} / \mathrm{m}^{2}$ had 1.5 times the risk of CC compared with those with BMI $<25 \mathrm{~kg} / \mathrm{m}^{2}$ [62]. More recently, a meta-analysis (five cohort and five case-control studies) revealed that being overweight (pooled OR 1.30, $95 \%$ CI 1.131.49) and obese (pooled OR 1.52, $95 \%$ CI 1.13-1.89) were significantly associated with CC [65].

Major physiological site of leptin action is in central nervous system. However, the receptors are also expressed in peripheral tissues including cholangiocytes [66]. Studies have demonstrated that serum leptin levels are increased in obesity and have been suggested as a risk factor for CC [66]. Besides leptin, other pro-inflammatory cytokines 
- Interleukin-6 (IL-6) and tumor necrosis factor (TNF) are linked strongly to obesity and have been found to have a role in development of CC [56]. Based on the current literature review, evidence of association of obesity with CC is growing and needs to be confirmed with long-term cohort studies. Research on the causal role of obesity and progression of different cancers including cholangiocarcinoma is evolving.

\section{Conclusion}

Obesity impacts the risk and outcomes of a broad spectrum of gastrointestinal diseases including esophageal reflux disease, nonalcoholic fatty liver disease, gallstone disease, and acute pancreatitis. As detailed in this review, this global pandemic also adversely influences the risk and prognosis of related gastrointestinal pre-malignant and malignant conditions. The influence of obesity appears to be a mixture of mechanical, humoral, pro-inflammatory, and complex metabolic mechanisms. These associations are worrisome since recent trends indicate increasing prevalence of obesity in children and adolescents. The implications include gastrointestinal malignancies which are difficult to manage especially in a younger patient population. Hence, there is an emergent need for focused research on increasing and improving operative, endoscopic, and non-invasive interventions for effectively containing the uncontrolled global surge in prevalence of obesity.

\section{Funding sources}

This publication was supported in part (Darwin L. Conwell) by the National Institutes of Diabetes and Digestive and Kidney Diseases (NIDDK) and National Cancer Institute (NCI) under Award Number U01DK108327.

\section{References}

1. Ng M, Fleming T, Robinson M, Thomson B, Graetz N, et al. (2014) Global, regional, and national prevalence of overweight and obesity in children and adults during 19802013: a systematic analysis for the Global Burden of Disease Study 2013. Lancet 384 766-781. [Crossref]

2. Ogden CL, Carroll MD, Kit BK, Flegal KM (2014) Prevalence of childhood and adult obesity in the United States, 2011-2012. JAMA 311: 806-814. [Crossref]

3. Sturm R, Hattori A (2013) Morbid obesity rates continue to rise rapidly in the United States. Int J Obes (Lond) 37: 889-891. [Crossref]

4. Wang YC, McPherson K, Marsh T, Gortmaker SL, Brown M (2011) Health and economic burden of the projected obesity trends in the USA and the UK. Lancet 378 : 815-825. [Crossref]

5. Majumder K, Gupta A, Arora N, Singh PP, Singh S. (2015) Premorbid Obesity and Mortality in Patients With Pancreatic Cancer: A Systematic Review and Meta-analysis. Clin Gastroenterol Hepatol 14: 355-e32. [Crossref]

6. Thrift AP, Shaheen NJ, Gammon MD, Bernstein L, Reid BJ, et al. (2014) Obesity and risk of esophageal adenocarcinoma and Barrett's esophagus: a Mendelian randomization study. J Natl Cancer Inst 106. [Crossref]

7. Singh S, Sharma AN, Murad MH, Buttar NS, El-Serag HB, et al. (2013) Centra adiposity is associated with increased risk of esophageal inflammation, metaplasia, and adenocarcinoma: a systematic review and meta-analysis. Clin Gastroenterol Hepatol 11: 1399-1412.e7. [Crossref]

8. Drahos J, Ricker W, Parsons R et al. (2015) Metabolic syndrome increases risk of Barrett esophagus in the absence of gastroesophageal reflux: an analysis of SEERMedicare Data. J Clin Gastroenterol 49: 282-288. [Crossref]

9. Garcia JM, Splenser AE, Kramer J, Alsarraj A, Fitzgerald S, et al. (2014) Circulating inflammatory cytokines and adipokines are associated with increased risk of Barrett's esophagus: a case-control study. Clin Gastroenterol Hepatol 12: 229-238 e223. [Crossref]

10. Greer KB, Thompson CL, Brenner L, Bednarchik B, Dawson D, et al. (2012) Association of insulin and insulin-like growth factors with Barrett's oesophagus. Gut 61: 665-672. [Crossref]

11. Pandolfino JE, El-Serag HB, Zhang Q, Shah N, Ghosh SK, et al. (2006) Obesity: a challenge to esophagogastric junction integrity. Gastroenterology 130: 639-649. [Crossref]

12. McElholm AR, McKnight AJ, Patterson CC, Johnston BT, Hardie LJ, et al. (2010) A population-based study of IGF axis polymorphisms and the esophageal inflammation, metaplasia, adenocarcinoma sequence. Gastroenterology 139: 204-212 e203. [Crossref]

13. Brown JC, Meyerhardt JA (2016) Obesity and Energy Balance in GI Cancer. J Clin Oncol 34: 4217-4224. [Crossref]

14. Siegel R, Desantis C, Jemal A (2014) Colorectal cancer statistics, 2014. CA Cancer J Clin 64: 104-117. [Crossref]

15. Ben Q, An W, Jiang Y, Zhan X, Du Y, et al. (2012) Body mass index increases risk for colorectal adenomas based on meta-analysis. Gastroenterology 142: 762-772. [Crossref]

16. Ma Y, Yang Y, Wang F, Zhang P, Shi C, et al. (2013) Obesity and risk of colorecta cancer: a systematic review of prospective studies. PLoS One 8: e53916. [Crossref]

17. Larsson SC, Wolk A (2007) Obesity and colon and rectal cancer risk: a meta-analysis of prospective studies. Am J Clin Nutr 86: 556-565. [Crossref]

18. Okabayashi K, Ashrafian H, Hasegawa H, Yoo JH, Patel VM, et al. (2012) Body mas index category as a risk factor for colorectal adenomas: a systematic review and metaanalysis. Am J Gastroenterol 107: 1175-1185. [Crossref]

19. (2011) Colorectal Cancer 2011 Report. Food, Nutrition, Physical Activity, and the Prevention of Colorectal Cancer. [cited June 2 2016]. [http://wwwaicrorg/continuousupdate-project/reports/Colorectal-Cancer-2011-Reportpdf]

20. Li R, Grimm SA, Chrysovergis K, Kosak J, Wang X, et al. (2014) Obesity, rather than diet, drives epigenomics alterations in colonic epithelium resembling cancer progression. Cell Metab 19: 702-711. [Crossref]

21. Moghaddam AA, Woodward M, Huxley R (2007) Obesity and risk of colorectal cancer: a meta-analysis of 31 studies with 70,000 events. Cancer Epidemiol Biomarkers Prev 16: 2533-2547. [Crossref]

22. Pischon T, Lahmann PH, Boeing H, Friedenreich C, Norat T, et al. (2006) Body size and risk of colon and rectal cancer in the European Prospective Investigation Into Cancer and Nutrition (EPIC). J Nat Cancer Inst 98: 920-931. [Crossref]

23. Siegel RL, Jemal A, Ward EM (2009) Increase in incidence of colorectal cancer among young men and women in the United States. Cancer Epidemiol Biomarkers Prev 18 1695-1698. [Crossref]

24. Joshu CE, Parmigiani G, Colditz GA, Platz EA (2012) Opportunities for the primary prevention of colorectal cancer in the United States. Cancer Prev Res (Phila) 5: 138145. [Crossref]

25. Schoen RE, Weissfeld JL, Kuller LH, Thaete FL, Evans RW, et al. (2005) Insulinlike growth factor-I and insulin are associated with the presence and advancement of adenomatous polyps. Gastroenterology 129: 464-475. [Crossref]

26. Shan HB, Zhang R, Li Y, Xu GL, Luo GY, et al. (2011) Expression of IGF-1R in colorectal polyps and its role in colorectal carcinogenesis. Technol Cancer Res Treat 10: 381-389. [Crossref]

27. Chen L, Li L, Wang Y, Li P, Luo L, et al. (2013) Circulating C-peptide level is a predictive factor for colorectal neoplasia: evidence from the meta-analysis of prospective studies. Cancer Causes Control 24: 1837-1847. [Crossref]

28. Chi F, Wu R, Zeng YC, Xing R, Liu Y (2013) Circulation insulin-like growth factor peptides and colorectal cancer risk: an updated systematic review and meta-analysis. Mol Biol Rep 40: 3583-3590. [Crossref]

29. Shiratsuchi I, Akagi Y, Kawahara A, Kinugasa T, Romeo K, et al. (2011) Expression of IGF-1 and IGF-1R and their relation to clinicopathological factors in colorectal cancer. Anticancer Res 31: 2541-2545. [Crossref]

30. Braun S, Bitton-Worms K, LeRoith D (2011) The link between the metabolic syndrome and cancer. Int J Biol Sci 7: 1003-1015. [Crossref]

31. Coussens LM, Werb Z (2002) Inflammation and cancer. Nature 420: 860-867. [Crossref]

32. Harvey AE, Lashinger LM, Hursting SD (2011) The growing challenge of obesity and cancer: an inflammatory issue. Ann N Y Acad Sci 1229: 45-52. [Crossref]

33. Hanahan D, Weinberg RA (2011) Hallmarks of cancer: the next generation. Cell 144 646-674. [Crossref] 
34. Sikaris KA (2004) The clinical biochemistry of obesity. Clin Biochem Rev 25: 165-181. [Crossref]

35. Villanueva EC, Myers MG Jr. (2008) Leptin receptor signaling and the regulation of mammalian physiology. Int J Obes (Lond) 32: S8-12. [Crossref]

36. Stattin P, Lukanova A, Biessy C, Söderberg S, Palmqvist R, et al. (2004) Obesity and colon cancer: does leptin provide a link? Int J Cancer 109: 149-152. [Crossref]

37. Hussan H, Gray DM, 2nd, Hinton A, Krishna SG, Conwell DL, et al. (2015) Morbid Obesity is Associated with Increased Mortality, Surgical Complications, and Incremental Health Care Utilization in the Peri-Operative Period of Colorectal Cancer Surgery. World J Surg 40: 987-994. [Crossref]

38. Dignam JJ, Polite BN, Yothers G, Raich P, Colangelo L, et al. (2006) Body mass index and outcomes in patients who receive adjuvant chemotherapy for colon cancer. $J$ Nat Cancer Inst 98: 1647-1654. [Crossref]

39. Gibson TM, Park Y, Robien K et al. (2014) Body mass index and risk of second obesityassociated cancers after colorectal cancer: a pooled analysis of prospective cohort studies. J Clin Oncol 32: 4004-4011. [Crossref]

40. Meyerhardt JA, Catalano PJ, Haller DG, Mayer RJ, Benson AB 3rd, et al. (2003) Influence of body mass index on outcomes and treatment-related toxicity in patients with colon carcinoma. Cancer 98: 484-495. [Crossref]

41. Campbell PT, Newton CC, Dehal AN et al. (2012) Impact of body mass index on survival after colorectal cancer diagnosis: the Cancer Prevention Study-II Nutrition Cohort. J Clin Oncol 30: 42-52

42. Rapp K, Schroeder J, Klenk J, Stoehr S, Ulmer H, et al. (2005) Obesity and incidence of cancer: a large cohort study of over 145,000 adults in Austria. Br J Cancer 93: 10621067. [Crossref]

43. Li D, Morris JS, Liu J, Hassan MM, Day RS, et al. (2009) Body mass index and risk, age of onset, and survival in patients with pancreatic cancer. JAMA 301: 2553-2562. [Crossref]

44. Rollins KE, Tewari N, Ackner A, Awwad A, Madhusudan S, et al. (2015) The impact of sarcopenia and myosteatosis on outcomes of unresectable pancreatic cancer or distal cholangiocarcinoma. Clin Nutr 35: 1103-1109. [Crossref]

45. Larsson SC, Permert J, Hakansson N, Näslund I, Bergkvist L, et al. (2005) Overall obesity, abdominal adiposity, diabetes and cigarette smoking in relation to the risk of pancreatic cancer in two Swedish population-based cohorts. Br J Cancer 2005; 93: 1310-1315. [Crossref]

46. Calle EE, Kaaks R (2004) Overweight, obesity and cancer: epidemiological evidence and proposed mechanisms. Nat Rev Cancer 4: 579-591. [Crossref]

47. Ng M, Fleming T, Robinson M, Thomson B, Graetz N, et al. (2014) Global, regional, and national prevalence of overweight and obesity in children and adults during 19802013: a systematic analysis for the Global Burden of Disease Study 2013. Lancet 384 766-781. [crossref]

48. Genkinger JM, Spiegelman D, Anderson KE, Bernstein L, van den Brandt PA, et al. (2011) A pooled analysis of 14 cohort studies of anthropometric factors and pancreatic cancer risk. Int J Cancer 129: 1708-1717. [Crossref]

49. Aune D, Greenwood DC, Chan DS, Vieira R, Vieira AR, et al. (2012) Body mass index, abdominal fatness and pancreatic cancer risk: a systematic review and non-linear doseresponse meta-analysis of prospective studies. Ann Oncol 23: 843-852. [Crossref]

50. Genkinger JM, Kitahara CM, Bernstein L, Berrington de Gonzalez A, Brotzman M, et al. (2015) Central adiposity, obesity during early adulthood, and pancreatic cance mortality in a pooled analysis of cohort studies. Ann Oncol 26: 2257-2266. [Crossref]

51. Philip B, Roland CL, Daniluk J, Liu Y, Chatterjee D, et al. (2013) A high-fat diet activates oncogenic Kras and COX2 to induce development of pancreatic ductal adenocarcinoma in mice. Gastroenterology 145: 1449-1458. [Crossref]

52. Sandini M, Bernasconi DP, Fior D, Molinelli M, Ippolito D, et al. (2016) A high viscera adipose tissue-to-skeletal muscle ratio as a determinant of major complications after pancreatoduodenectomy for cancer. Nutrition 32: 1231-1237. [Crossref]

53. Pecorelli N, Carrara G, De Cobelli F, Cristel G, Damascelli A, et al. (2016) Effect of sarcopenia and visceral obesity on mortality and pancreatic fistula following pancreatic cancer surgery. Br J Surgery 103: 434-442. [Crossref]

54. Tan BH, Birdsell LA, Martin L, Baracos VE, Fearon KC (2009) Sarcopenia in an overweight or obese patient is an adverse prognostic factor in pancreatic cancer. Clin Cancer Res 15: 6973-6979. [Crossref]

55. Society AC (2016) Cancer Facts \& Figures 2016. In: American Cancer Society Atlanta, GA, USA.
56. Braicu C, Burz C, Berindan-Neagoe I, Balacescu O, Tantau M, et al. (2009) Molecular Markers in the Pathogenesis of Cholangiocarcinoma: Potential for Early Detection and Selection of Appropriate Treatment. Gastroenterology Res 2: 132-140. [Crossref]

57. El-Serag HB, Rudolph KL (2007) Hepatocellular carcinoma: epidemiology and molecular carcinogenesis. Gastroenterology 132: 2557-2576. [Crossref]

58. Calle EE, Rodriguez C, Walker-Thurmond K, Thun MJ (2003) Overweight, obesity, and mortality from cancer in a prospectively studied cohort of US adults. $N$ Engl J Med 348: 1625-1638. [Crossref]

59. Kew MC (2015) Obesity as a cause of hepatocellular carcinoma. Ann Hepatol 14: 299303. [crossref]

60. Connolly G, Safadjou S, Kashyap R, Chen R, Ndauguba A, et al. (2011) Impact of diabetes mellitus on risk of major vessel invasion and distant metastasis in hepatocellular carcinoma. In: ASCO Annual Meeting Proceedings: 174.

61. Ohki T, Tateishi R, Shiina S, Goto E, Sato T, et al. (2009) Visceral fat accumulation is an independent risk factor for hepatocellular carcinoma recurrence after curative treatment in patients with suspected NASH. Gut 58: 839-844. [Crossref]

62. Grainge MJ, West J, Solaymani-Dodaran M, Aithal GP, Card TR (2009) The antecedents of biliary cancer: a primary care case-control study in the United Kingdom. $\mathrm{Br} J$ Cancer 100: 178-180. [Crossref]

63. Welzel TM, Graubard BI, El-Serag HB, Shaib YH, Hsing AW, et al. (2007) Risk factor for intrahepatic and extrahepatic cholangiocarcinoma in the United States: a populationbased case-control study. Clin Gastroenterol Hepatol 5: 1221-1228. [Crossref]

64. Welzel TM, Mellemkjaer L, Gloria G, Sakoda LC, Hsing AW, et al. (2007) Risk factors for intrahepatic cholangiocarcinoma in a low-risk population: a nationwide casecontrol study. Int J Cancer 120: 638-641. [Crossref]

65. Li JS, Han TJ, Jing N, Li L, Zhang XH, et al. (2014) Obesity and the risk of cholangiocarcinoma: a meta-analysis. Tumour Biol 35: 6831-6838. [Crossref]

66. Fava G, Alpini G, Rychlicki C, Saccomanno S, DeMorrow S, et al. (2008) Leptin enhances cholangiocarcinoma cell growth. Cancer Res 68: 6752-6761. [Crossref]
Copyright: (C2017 Krishna SG. This is an open-access article distributed under the terms of the Creative Commons Attribution License, which permits unrestricted use, distribution, and reproduction in any medium, provided the original author and source are credited. 